\title{
Thermal imaging test of the disk brake of a diesel multiple unit in field conditions
}

\section{Badanie termowizyjne hamulca tarczowego spalinowego zespołu trakcyjnego $\mathrm{w}$ warunkach poligonowych}

\begin{abstract}
The article presents the methodology of thermal imaging tests of a disc brake of a DB Link III rail vehicle performed in field conditions. The test methodology was developed on the example of the above-mentioned vehicle, and the temperature distribution of the brake disc during braking was measured. In the article, particular attention was paid to the configuration of the thermal imaging camera to the actual conditions occurring during the test. It is important because due to the rotating brake disc, it is difficult to verify the temperature value with another contact type measuring device. In exceptional cases, temperature measurement with the use of thermocouples is used, but it requires an extensive additional measuring system, which will significantly extend the time of preparing the vehicle for testing and increase its costs. Although the temperature is measured indirectly with the thermal imager, the correct configuration of the camera settings to the real conditions may affect the measurement error by several percent.

$W$ artykule zaprezentowano metodykę badań termowizyjnych hamulca tarczowego pojazdu szynowego DB Link III w warunkach poligonowych. Na przyktadzie wspomnianego pojazdu opracowano metodyke badań oraz przeprowadzono pomiar rozkladu temperatury tarczy hamulcowej $w$ czasie hamowania. W artykule szczególnq uwage zwrócono na konfiguracje kamery termowizyjnej do rzeczywistych warunków wystęujacych podczas badania. Jest to istotne, gdyz ze względu na obracajqca się tarczę hamulcowa, utrudniona jest weryfikacja wartości temperatury innym stykowym przyrzadem pomiarowym. W wyjatkowych sytuacjach stosuje sie pomiar temperatury z zastosowaniem termopar, jednak wymaga to rozbudowanego dodatkowego uktadu pomiarowego, co znaczqco wydluży czas przygotowania obiektu do badań $i$ zwiększy jego koszty. Mimo, że kamera termowizyjna dokonuje się pomiaru temperatury $w$ sposób pośredni, prawidlowa konfiguracja ustawień kamery do warunków rzeczywistych, może wptynać na kilku procentowy bład pomiaru.
\end{abstract}

\section{INTRODUCTION}

Thermal imaging, as well as the term thermography, define a research method that allows the observation and registration of images in the infrared. The difference between thermography and thermal imaging lies in the order of establishing the image recording and observation. In thermography, the primary process is image registration and then its observation. On the other hand, in thermal imaging, images are first observed, for example on the screen of a thermal imaging camera, and only then are recorded and analyzed with the available tools for processing IR images [8].

Any object with a temperature higher than absolute zero, i.e. $0 \mathrm{~K}\left(-273.15{ }^{\circ} \mathrm{C}\right)$ emits energy in the form of infrared radiation, but this emission is continuous and

\section{WSTĘP}

Termowizja jak również termin termografia, określa metodę badawcza pozwalająca na obserwację i rejestrację obrazów w podczerwieni. Różnica pomiędzy termowizją a termografią występuje w kolejności ustalenia procesów rejestracji i obserwacji obrazu. W termografii procesem pierwotnym jest rejestracja obrazu a następnie jego obserwacja. Natomiast w termowizji, najpierw obserwuje się obrazy np. na ekranie kamery termowizyjnej a dopiero później dokonuje się jego rejestracji i analizie przy dostępnych narzędziach obróbki zdjęć IR [8].

Każde ciało które posiada temperaturę wyższą od zera bezwzględnego tj. $0 \mathrm{~K}\left(-273,15^{\circ} \mathrm{C}\right)$ emituję energię $\mathrm{w}$ postaci promieniowania podczerwonego, 
the radiation energy depends on the temperature and wavelength [6]. Infrared radiation is a form of electromagnetic radiation with a wavelength between those of visible light and microwaves. It is formed as a result of vibrations of atoms and molecules which make up every physical body. Infrared radiation is thermal and its wavelength range reaches from $0.780 \mu \mathrm{m}$ up to about $1000 \mu \mathrm{m}$ [10].

A thermal imaging camera or a pyrometer, as a device for non-contact temperature measurement, records infrared radiation in a selected range of electromagnetic waves by means of an integrated infrared detector. An infrared detector located in a thermal imaging camera converts the energy from incident photons of infrared radiation in that wavelength range into an electrical signal whose level depends on the temperature of the tested object [7]. The received signal is then visualized on the so-called thermogram in the form of a black-and-white or color image. The tested objects emit radiation with a certain power value, this power is called luminance. This makes it possible to record the temperature distribution on the thermograms.

In addition to the detector, the thermal imaging camera, as shown in Figure 1, consists of a lens, lens diaphragm, electronic system, display, control buttons, storage media and software for recording and analyzing measurement results.

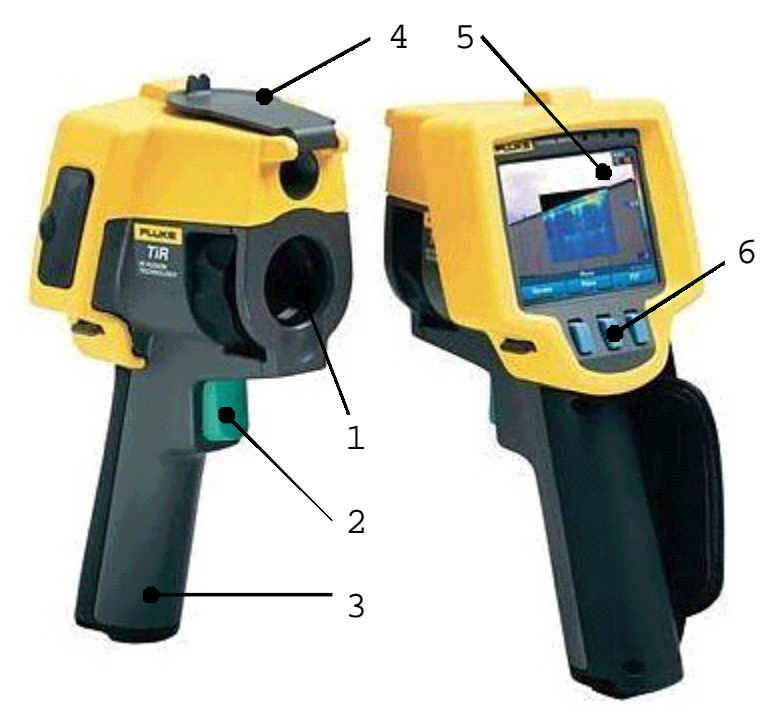

Fig. 1. Image and design of the FLUKE thermal imaging camera; 1 - lens, 2 - trigger, 3 - camera handle, 4 - lens aperture, 5 - display, 6 - control buttons [3]

Rys. 1. Widok i budowa kamery termowizyjnej FLUKE; 1obiektyw, 2 - wyzwalacz, 3 - uchwyt kamery, 4 - przysłona obiektywu, 5 - wyświetlacz, 6 - przyciski sterujące [3]

Thermal imaging cameras are classified according to several criteria. The first depends on how the camera is used. These instruments allow observation of the tested objects or only a temperature measurement. Both types of cameras use measuring transducers called detectors. The type of detector used is the next part of classification. The detector types include bolometric, pyroelectric and radiation. It should be emphasized that jednak emisja ta jest ciagła a energia promieniowania jest zależna od wartości temperatury oraz długości fali [6]. Promieniowanie podczerwone jest promieniowaniem elektromagnetycznym o długości fal pomiędzy światłem widzialnym a mikrofalami. Powstaje w wyniku drgań atomów i cząsteczek, z których zbudowane jest każde ciało. Promieniowanie podczerwone ma charakter cieplny, jest ciagłe, a zakres długości jego fali mieści się od $0,780 \mu \mathrm{m}$ do ok. $1000 \mu \mathrm{m}[10]$.

Kamera termowizyjna czy pirometr jako przyrząd do bezstykowego pomiary temperatury rejestruje promieniowanie podczerwone w wybranym zakresie fal elektromagnetycznych za pomoca wbudowanego detektora podczerwieni. Detektor podczerwieni usytuowany w kamerze termowizyjnej przetwarza energię pochodzącą od padających fotonów promieniowania podczerwonego na sygnał elektryczny którego poziom zależny jest od temperatury obiektu badanego [7]. Otrzymany sygnał wizualizowany jest na tzw. termogram w postaci obrazu biało-czarnego lub barwnego. Badane obiekty wysyłają promieniowanie o określonej wartości mocy, moc ta nazywana jest luminacją. Poprzez to na termogramach możemy zarejestrować rozkład temperatur.

Oprócz detektora, kamera termowizyjna, co przedstawia rysunek 1 składa się obiektywu, przesłony obiektywu, układ elektronicznego, wyświetlacz, przycisków sterujących, nośniki pamięci oraz oprogramowania rejestrującego i analizującego wyniki pomiarów.

Kamery termowizyjne klasyfikuje się według kilku kryteriów. Pierwszym z nich jest sposób użycia kamery. Przyrządy te umożliwiają obserwację badanych obiektów lub umożliwia wyłącznie pomiar. Oba typy kamer wykorzystuja przetworniki pomiarowe nazywane detektorami. Rodzaj zastosowanego detektora jest następnym kryterium podziału. Detektory podzielić można na bolometryczne, piroelektryczne oraz radiacyjne. Kamery bolometryczne są najczęściej stosowanymi przyrządami ze względu na najszerszy zakres rejestrowanej długości fali podczerwonej.

\section{EMISYJNOŚĆ W BADANIACH TERMO- WIZYJNYCH}

Każde badanie termowizyjne poprzedzone musi być konfiguracją ustawień kamery do warunków jakie panowały w czasie badań. Szczególną uwagę należy zwrócić na ustawienie emisyjności (współczynnika $\varepsilon)$. Pozostałe parametry jak temperatura odbita, temperatura otoczenia oraz wilgotność powietrza. mogą spowodować błąd pomiaru w granicach 1 lub $2{ }^{\circ} \mathrm{C}$ [9]. Emisyjność określana jest jako zdolność do emisji promieniowania rzeczywistej powierzchni badanej w odniesieniu do ciała doskonale czarnego. Jest równa 
bolometric cameras are the most frequently used devices due to the widest range of the recorded infrared wavelength.

\section{RADIATION IN THERMAL IMAGING RE- SEARCH}

Each thermal imaging test must be preceded by the camera settings configuration to the conditions present during the tests. The emissivity ( $\varepsilon$-factor) setting should be considered the most important part of this process. Other parameters such as reflected temperature, ambient temperature and air humidity, may lead to a measurement error within the range of 1 or $2{ }^{\circ} \mathrm{C}$ [9]. The emissivity is defined as the ability to emit radiation from the actual tested surface in relation to the black body radiation. It is equal to the ratio of the radiation intensity of the real surface to the radiation intensity of a black body, assuming the same temperature of both bodies [11]. The relationship is presented by the equation:

$$
\varepsilon=\frac{W_{C R}}{W_{D C}}
$$

where: $\mathrm{W}_{\mathrm{DC}}-$ black body radiation,

$\mathrm{W}_{\mathrm{CR}}$ - radiation of the measured object.

The value of the $\varepsilon$-factor depends on factors such as the material of the tested object, its temperature, the radiated wavelength as well as the condition of its surface [9]. Real objects typically have an emissivity factor ranging from 0.1 to 0.95 . Well-polished surfaces have an emissivity factor below 0.1 because they reflect approximately $98 \%$ of external radiation. On the other hand, surfaces painted with paint (in particular black) or oxidized have an emissivity factor above 0.9 [10].

In thermal imaging research three methods of determining the emissivity are used, these methods are:

- calorimetric,

- reflective,

- with a reference object.

In the calorimetric method, the emissivity factor can be determined in two ways. In the first case, a camera measuring spectral exitance should be used, in which the emissivity of the material is selected in order to obtain the same resulting temperature value as measured by the contact method (e.g. with a thermocouple). The second way is to calculate the radiant exitance emitted by the tested object according to equation (2) [11].

$$
M(T)=\varepsilon M_{C}\left(T_{O}\right)+(1-\varepsilon) M_{\alpha}\left(T_{\alpha}\right)
$$

where: $\mathrm{M}_{\mathrm{c}}\left(\mathrm{T}_{\mathrm{o}}\right)-$ radiant exitance of a black body at a temperature of the object $T_{0}$,

$\mathrm{M}_{\alpha}\left(\mathrm{T}_{\alpha}\right)$ - radiant exitance of the background at a temperature $\mathrm{T}_{\alpha}$. stosunkowi natężenia promieniowania powierzchni rzeczywistej do natężenia promieniowania ciała doskonale czarnego, przy założeniu tej samej temperatury obydwu ciał [11]. Zależność przedstawia równanie:

\section{EMISYJNOŚĆ W BADANIACH TERMO- WIZYJNYCH}

Każde badanie termowizyjne poprzedzone musi być konfiguracją ustawień kamery do warunków jakie panowały w czasie badań. Szczególną uwagę należy zwrócić na ustawienie emisyjności (współczynnika $\varepsilon)$. Pozostałe parametry jak temperatura odbita, otoczenia oraz wilgotność powietrza. moga spowodować błąd pomiaru w granicach 1 lub $2{ }^{\circ} \mathrm{C}$ [9]. Emisyjność określana jest jako zdolność do emisji promieniowania rzeczywistej powierzchni badanej w odniesieniu do ciała doskonale czarnego. Jest równa stosunkowi natężenia promieniowania powierzchni rzeczywistej do natężenia promieniowania ciała doskonale czarnego, przy założeniu tej samej temperatury obydwu ciał [11]. Zależność przedstawia równanie:

$$
\varepsilon=\frac{W_{C R}}{W_{D C}}
$$

gdzie: $\mathrm{W}_{\mathrm{DC}}-$ promieniowanie ciała doskonale czarnego,

$$
\mathrm{W}_{\mathrm{CR}} \text { - promieniowanie ciała rzeczywistego. }
$$

Wartość współczynnika zależna jest od takich czynników jak rodzaj ciała, jego temperatura, długości fali promieniowanej jak również od stanu powierzchni [9]. Obiekty rzeczywiste mają współczynnik emisyjności $w$ zakresie od 0,1 do 0,95 . Powierzchnie dobrze wypolerowane posiadają emisyjność na poziomie poniżej wartości 0,1 gdyż odbijaja około $98 \%$ promieniowania pochodzacego $\mathrm{z}$ zewnatrz. Natomiast powierzchnie pomalowane farbą (w szczególności czarna) oraz oksydowane charakteryzują się współczynnik emisyjności powyżej 0,9 [10].

W badaniach termowizyjnych wykorzystuje się trzy sposoby wyznaczenia emisyjności, jest to metoda:

- kalorymetryczna,

- odbiciowa,

- z ciałem referencyjnym.

W metodzie kalorymetrycznej współczynnik emisyjność można wyznaczyć na dwa sposoby. W pierwszym przypadku należy zastosować kamerę mierzącą egzytancję widmowa, w której dobiera się emisyjność materiału w celu uzyskania wartości temperatury takiej samej jak przy zmierzeniu metodą stykową (np. termopara). W drugim przypadku należy obliczyć egzytancję widmową emitowaną przez badany obiekt zgodnie z zależnością (2) [11]. 
Using the Stefan-Boltzmann law, it is possible to determine the value of the exitance knowing the temperature of the object $\mathrm{T}_{\mathrm{o}}$ and the ambient (background) temperature $T_{\alpha}$, according to the relations [7]:

$$
\begin{aligned}
& M_{C}\left(T_{O}\right)=\sigma T_{O}^{4} \\
& M_{\alpha}\left(T_{\alpha}\right)=\sigma T_{\alpha}^{4}
\end{aligned}
$$

Then the actual emissivity of the tested object is determined from the dependence (5) [11].

$$
\varepsilon=\frac{T^{4}-T_{\alpha}^{4}}{T_{O}^{4}-T_{\alpha}^{4}}
$$

where: $\mathrm{T} \quad-\quad$ radiation temperature indicated by the thermal imaging camera when $\varepsilon=1$.

In the reflection method, the tested object is illuminated twice, once by each of two heat sources $Z_{1}$ and $Z_{2}$, which have different temperatures. The following radiation data reaches the camera during such a test:

- of two heat sources $Z_{1}$ and $Z_{2}$,

- reflected from the object $(1-\varepsilon) \mathrm{M}_{\mathrm{Z} 1}$ or $(1-\varepsilon) \mathrm{M}_{\mathrm{Z} 2}$,

- reflected from the mirror $\mathrm{M}_{\mathrm{Z} 1}$ or $\mathrm{M}_{\mathrm{Z} 2}$,

- own radiation of the tested object $\varepsilon \mathrm{M}_{\mathrm{c}}\left(\mathrm{T}_{0}\right)$.

The emissivity in the reflection method is determined from the equation (6) [11].

$$
\varepsilon=1-\frac{M_{1}-M_{2}}{M_{Z 1}-M_{Z 2}}
$$

where: $M_{1}, M_{2}$ - the exitance of the examined body illuminated by the sources $Z_{1}$ and $Z_{2}$,

$\mathrm{M}_{\mathrm{Z} 1}, \mathrm{M}_{\mathrm{Z} 2}$ - camera band exitance for the first and second light source.

However, in the reference body method, a test and reference object with a known emissivity $\varepsilon_{\mathrm{r}}$ is used. During the measurement, these bodies are close to the tested object, so that the background radiation has the same effect on both objects observed. Thus the temperature $T_{0}$ for both bodies is the same. Then, the exitance of the reference body and the tested body is determined, while the actual emissivity of the tested object is determined from the equation (7) [11].

$$
\varepsilon=\varepsilon_{r} \frac{M_{1}-M_{a}}{M_{2}-M_{a}}
$$

where: $\mathrm{M}_{1}, \mathrm{M}_{2}$ - the exitance of the tested body and the reference body,

$\mathrm{M}_{\alpha}$-background radiation energy is determined by replacing the tested material with a mirror with a reflection coefficient $\rho \approx 1$ [11], $\mathrm{E}_{\mathrm{r}}-$ the emissivity of the reference body.

$$
M(T)=\varepsilon M_{C}\left(T_{O}\right)+(1-\varepsilon) M_{\alpha}\left(T_{\alpha}\right)
$$

gdzie: $\mathrm{M}_{\mathrm{c}}\left(\mathrm{T}_{\mathrm{o}}\right)$ - egzytancja ciała doskonale czarnego o temperaturze obiektu $T_{0}$,

$$
\mathrm{M}_{\alpha}\left(\mathrm{T}_{\alpha}\right) \quad-\text { egzytancje tha o temperaturze } \mathrm{T}_{\alpha} \text {. }
$$

Na podstawie prawa Stefana-Boltzmanna możliwe jest wyznaczenie wartość egzytancji znając odpowiednio temperatury obiektu $T_{o}$ i otoczenia (tła) $T_{\alpha}$, zgodnie z zależnościami [7]:

$$
\begin{aligned}
& M_{C}\left(T_{O}\right)=\sigma T_{O}^{4} \\
& M_{\alpha}\left(T_{\alpha}\right)=\sigma T_{\alpha}^{4}
\end{aligned}
$$

Następnie rzeczywistą emisyjność badanego obiektu wyznacza się z zależności (5) [11].

$$
\varepsilon=\frac{T^{4}-T_{\alpha}^{4}}{T_{O}^{4}-T_{\alpha}^{4}}
$$

gdzie: T - temperatura radiacyjna wskazywana przez kamerę termowizyjną gdy $\varepsilon=1$.

W metodzie odbiciowej badany obiekt jest dwa razy oświetlany przez dwa źródła ciepła $Z_{1}$ i $Z_{2}$, które mają temperatury o wartościach różniących się od siebie. Do kamery podczas badania docierają następujące promieniowania:

- dwóch źródeł ciepła $Z_{1}$ i $Z_{2}$,

- odbite od obiektu $(1-\varepsilon) \mathrm{M}_{\mathrm{Z} 1}$ lub $(1-\varepsilon) \mathrm{M}_{\mathrm{Z} 2}$,

- odbite od zwierciadła $\mathrm{M}_{\mathrm{Z1}}$ lub $\mathrm{M}_{\mathrm{Z} 2}$,

- własne badanego obiektu $\varepsilon \mathrm{M}_{\mathrm{c}}\left(\mathrm{T}_{0}\right)$.

Emisyjność w metodzie odbiciowej wyznacza się $\mathrm{z}$ zależności (6) [11].

$$
\varepsilon=1-\frac{M_{1}-M_{2}}{M_{Z 1}-M_{Z 2}}
$$

gdzie: $\mathrm{M}_{1}, \mathrm{M}_{2}$ - egzytancja badanego ciała oświetlanego ze źródła $Z_{1}$ i $Z_{2}$,

$M_{Z 1}, M_{Z 2}$ - egzytancje w paśmie kamery dla źródła pierwszego i drugiego światła.

Natomiast w metodzie z ciałem referencyjnym stosuje się obiekt badany i referencyjny o znanej emisyjności $\varepsilon_{\mathrm{r}}$. Ciało te podczas pomiaru usytuowane są blisko badanego obiektu, tak aby promieniowanie tła oddziaływało jednakowo na oba obiekty. Wówczas temperatura $T_{0}$ dla obu ciał jest jednakowa. Następnie wyznacza się egzytancję ciała referencyjnego oraz badanego, natomiast rzeczywista emisyjność badanego obiektu wyznacza się z zależności (7) [11].

$$
\varepsilon=\varepsilon_{r} \frac{M_{1}-M_{a}}{M_{2}-M_{a}}
$$

gdzie: $\mathrm{M}_{1}, \mathrm{M}_{2}$ - egzytancja badanego ciała oraz referencyjnego, 
It should be noted that in thermal imaging studies of objects, the emissivity coefficient is most often determined using the calorimetric method or with a reference body. In the first case, the temperature value is measured both with the contact method in a selected place and with a thermal imaging camera. In the camera settings, changes in the emissivity value until the temperature values in both measurements (with the use of e.g. a thermocouple and thermal imaging) are the same. In this case, the value of the background temperature is important [10]. In the second case (the method using the reference body), two measurements of the temperature value are made: the reference body and the test object. The background temperature value is also important in this case. The value of the emissivity of the object and the reference body is changed so that the temperature value of both bodies is the same [8].

\section{RESEARCH METHOD}

\subsection{Test object}

The subject of the thermal imaging tests was the disc brake assembly on the central trolley of the Deutsche Bahn DB Link III 633 series (BR633) vehicle, the vehicle was shown in Figure 2.

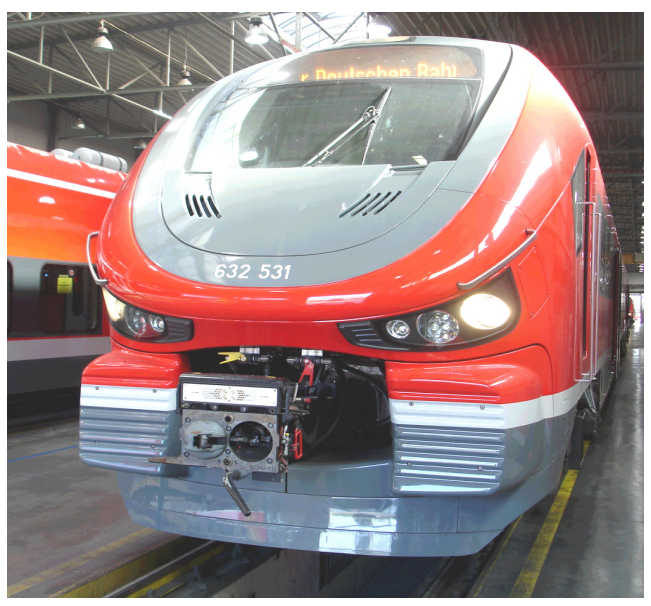

Fig. 2. Deutsche Bahn DB Link III 633 series (BR633) vehicle Rys. 2. Widok pojazdu DB Link III serii 633

The test object was a three-unit diesel vehicle manufactured at PESA Bydgoszcz SA. The type approval process was completed in 2018. A total of 71 Link I, II and III vehicles were produced for Deutsche Bahn [2]. Figure 3 shows a fragment of the vehicle's bogie with a brake caliper.

The vehicle was equipped with a friction disc brake, with discs fixed to the wheel on both rolling and driving bogies, as well as a magnetic rail brake. The vehicle was fitted with a Knorr-Bremse brake system.

\subsection{Test method}

A FLIR e60 microbolometer camera was used (Fig. 4) in the thermal imaging tests, the purpose of which was to determine the temperature distribution of the brake disc during braking of the DB Link III 633 vehicle.
$\mathrm{M}_{\alpha}-$ energia promieniowania tła, wyznacza się zastępując badany materiał zwierciadłem o współczynniku odbicia $\rho \approx 1$ [11],

$\mathrm{E}_{\mathrm{r}}$-emisyjność ciała referencyjnego.

Należy podkreślić, że w badaniach termowizyjnych obiektów najczęściej współczynnik emisyjności wyznaczany jest metodą kalorymetryczną lub z ciałem referencyjnym. W pierwszym przypadku pomiaru wartości temperatury dokonuje się zarówno metodą stykową w wybranym miejscu jak i kamerą termowizyjna. W ustawieniach kamery dokonuje się tak długo zmiany wartości emisyjności, aby wartości temperatury w obu pomiarach (stykowym z zastosowaniem np. termopary jak i termowizyjnym) były takie same. Ważna jest w tym przypadku wartość temperatury tła [10]. W drugim przypadku (metoda $\mathrm{z}$ ciałem referencyjnym) dokonuje się dwóch pomiarów wartości temperatury: ciała referencyjnego i obiektu badanego. W tym przypadku również jest ważna wartość temperatury tła. Dokonuje się zmiany wartości emisyjności obiektu i ciała referencyjnego, tak by wartość temperatury obu ciał była taka sama [8].

\section{METODYKA BADAŃ}

\subsection{Obiekt badań termowizyjnych}

Obiektem badań termowizyjnych był zespół hamulca tarczowego znajdujący się na wózku środkowym pojazdu Deutsche Bahn DB Link III serii 633 (BR633), widok pojazdu przedstawia rysunek 2.

Pojazd jest trójczłonowym spalinowym zespołem trakcyjnym wyprodukowanym $\mathrm{w}$ zakładach PESA Bydgoszcz SA. Proces homologacji zakończył się w 2018 roku. Dla Deutsche Bahn wyprodukowano w sumie 71 pojazdów w wersji Link I, II i III [2]. Na rysunku 3 przedstawiono widok fragmentu wózka tocznego pojazdu wraz z zaciskiem hamulcowym

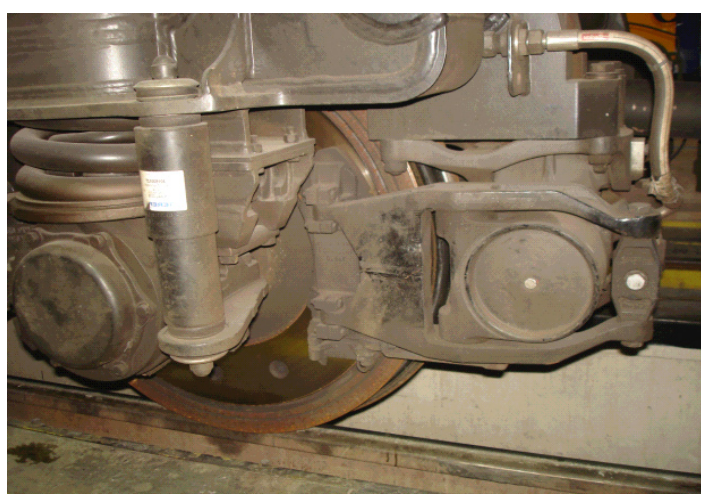

Fig. 3. View of the disc brake caliper on the center trolley of the DB Link III vehicle

Rys. 3. Widok zacisku hamulca tarczowego na wózku środkowym pojazdu DB Link III

Pojazd wyposażony jest w cierny hamulec tarczowy, z tarczami mocowanymi do koła zarówno na wózkach tocznych jak i napędnych oraz w szynowy hamulec magnetyczny. Pojazd wyposażony jest w układ hamulcowy z firmy Knorr-Bremse. 

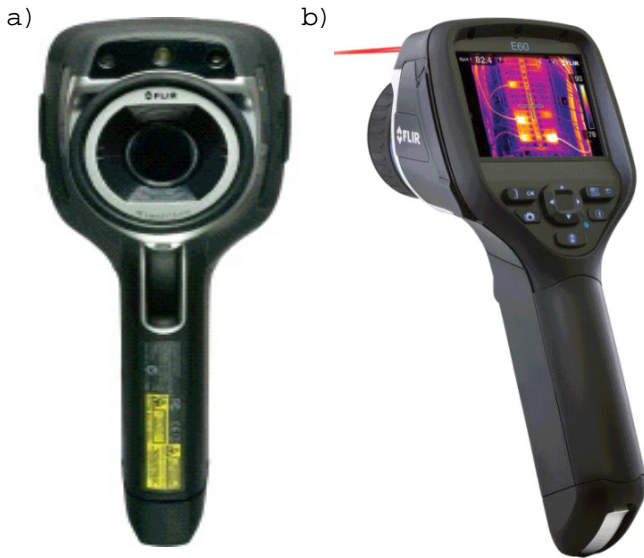

Fig. 4. FLIR e60 camera used during the research; a) view from the lens side, $b$ ) view from the camera display side [4]

Rys. 4. Widok kamery FLIR e60 zastosowanej podczas badań; a) widok od strony obiektywu, b) widok od strony wyświetlacza kamery [4]

Before the research was carried out, it was necessary to identify the origin of the various IR radiation sources. The camera settings required supplementing the following values: object emissivity, ambient temperature, reflected apparent temperature, distance between the object and the camera, and relative humidity.

During the configuration of the IR camera for use in real conditions, the most important aspect was setting the emission factor $\varepsilon$, as it has the greatest impact on the recorded temperature value. The calorimetric method described in chapter 2 was used. First, the temperature of the brake disc was measured with a sheath thermocouple, as shown in Figure 5, and then the $\varepsilon$ factor was set to the temperature value in the IR camera close to the temperature value obtained on the temperature sensor.

Several photos were taken using a thermal imaging camera simultaneously with the temperature measurement with the use of a sheathed contact probe. Figures 6 show an example of the brake disc temperature distribution with the marked points $\mathrm{Sp} 1, \mathrm{Sp} 2$ and $\mathrm{Sp} 3$ on three radii of the brake disc. Three temperatures were read at the contact points and then averaged.
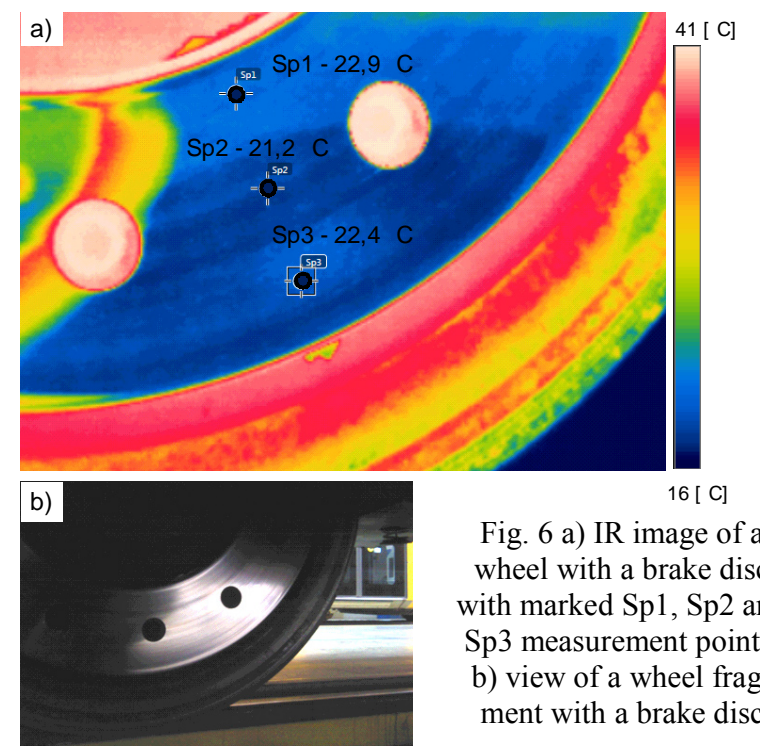

Fig. 6 a) IR image of a wheel with a brake disc with marked $\mathrm{Sp} 1, \mathrm{Sp} 2$ and Sp3 measurement points, b) view of a wheel fragment with a brake disc

\subsection{Metoda badań}

W badaniach termowizyjnych, których celem było wyznaczenie rozkładu temperatury tarczy hamulcowej w czasie hamowania pojazdu DB Link III 633, zastosowano kamerę mikrobolometrycznej typu FLIR e60 (rys. 4).

Przed badaniami zidentyfikowano pochodzenie różnych źródeł promieniowania. W ustawieniach kamery wprowadzono następujące wielkości: emisyjność obiektu, temperaturę otoczenia, temperaturę odbita pozorna, odległość obiektu od kamery oraz wilgotność względną.

Najwięcej uwagi podczas konfiguracji kamery IR do warunków rzeczywistych zwrócono na ustawienie współczynnika emisyjnego $\varepsilon$, gdyż największym stopniu wpływa on na wartość mierzonej temperatury. Zastosowano metodę kalorymetryczną opisaną jako pierwszą $\mathrm{w}$ rozdziale 2 . W pierwszej kolejności zmierzono termopara płaszczową temperaturę tarczy hamulcowej, co przedstawia rysunek 5, a następnie ustawiono współczynnik $\varepsilon$ do wartości temperatury w kamerze IR zbliżonej do wartości temperatury zmierzonej termoparą.

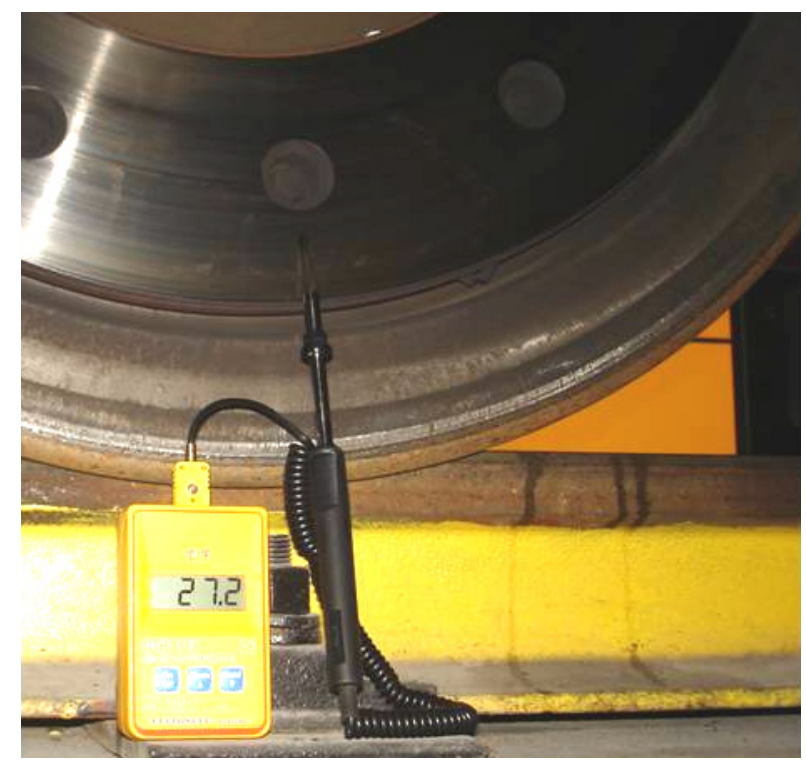

Fig. 5 Method of temperature measurement of the disc before testing with the GTH 1179 temperature sensor with a sheath probe

Rys. 5 Widok pomiaru temperatury tarczy przed badaniami $\mathrm{z}$ użyciem czujnika temperatury GTH 1179 z sondą płaszczową

Jednocześnie z pomiarem temperatury z zastosowaniem stykowej termopary płaszczowej, wykonano kilka zdjęć kamerą termowizyjną. Na rysunkach 6 przestawiono przykładowy rozkłady temperatury tarczy hamulcowej z naniesionymi punktami Sp1 Sp2 i Sp3 na trzech promieniach tarczy hamulcowej. W punktach styku termopar odczytano wartości trzech temperatur, które następnie były uśrednione.

Rys. 6 a) obraz IR koła z tarczą hamulcową z naniesionymi punktami pomiarowymi $\mathrm{Sp} 1, \mathrm{Sp} 2$ i Sp3, b) widok fragmentu koła z tarczą hamulcową 
Then, in the IR camera settings, the radiation emissivity value was changed in order to obtain the same value or a similar temperature on the display as the value obtained using the contact measurement with a sheath probe. The camera configuration in terms of determining the $\varepsilon$-factor was carried out for several points on the brake disc. The emissivity factor value obtained this way was 0.24 . For all tests, the smallest and the largest difference in temperature values obtained from the thermal imaging and contact measurements were determined. Then, in accordance with the relationship (1), the relative percentage error was determined on the basis of [5] of the thermal imaging measurement compared to the measurement with the use of a thermocouple.

$$
\delta=\frac{\left|x-x_{z}\right|}{x} \cdot 100 \%
$$

where: $x$ - measurement obtained using a sheathed thermocouple,

$x_{z}$ - measurement obtained using a thermal imaging camera.

In the process of configuring the thermal imaging camera and after applying the relationship (8), the minimum error of the IR camera was $4 \%$ and the maximum error $17 \%$ relative to the contact measurement.

After all the necessary data had been entered, the camera was mounted in a housing attached to the trolley frame on the vehicle chassis, on the opposite side of the recorded element, as shown in Figure 7. The camera was placed about $1 \mathrm{~m}$ away from the tested element.
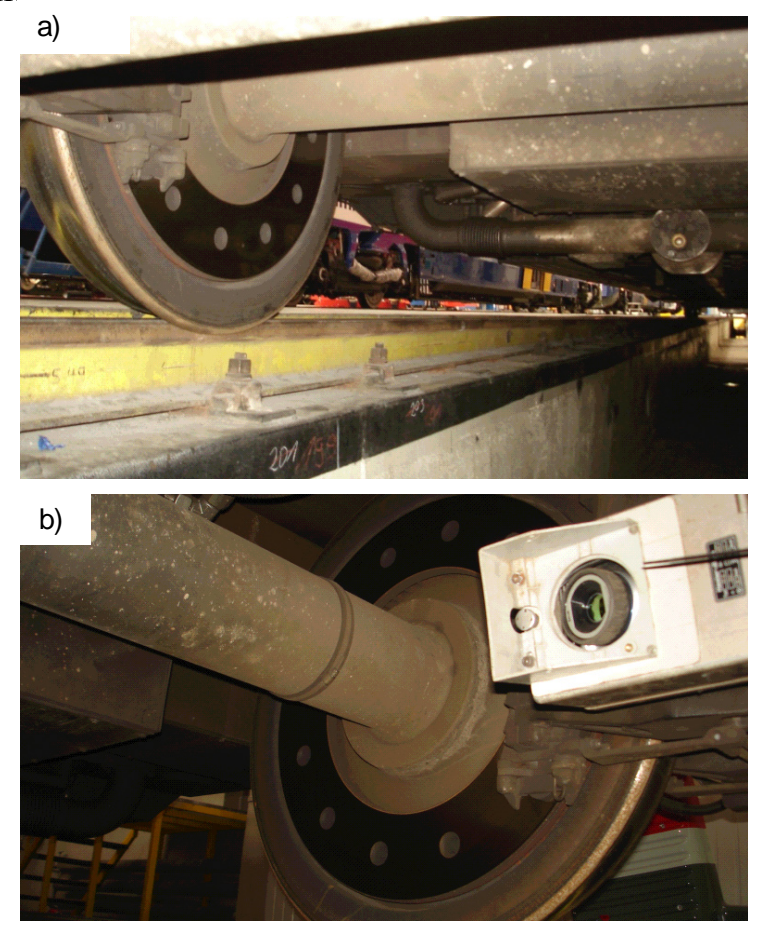

Fig. 7 a) view of the tested brake disc on the vehicle's chassis, b) view of the mounted housing with a thermal imaging camera

Rys. 7 a) widok badanej tarczy hamulcowej na podwoziu pojazdu, b) widok zamocowanej obudowy wraz z kamerą termowizyj-
Następnie w ustawieniach kamery IR zmieniano wartość emisyjności, w celu uzyskania na wyświetlaczu tej samej wartości lub zbliżonej temperatury jak przy pomiarze stykowym z termopara płaszczową. Konfigurację kamery w zakresie wyznaczenia współczynnika $\varepsilon$ przeprowadzono dla kilku obszarów tarczy hamulcowej. W ten sposób uzyskano wartość współczynnika emisyjności wynoszącą 0,24. Dla wszystkich prób wyznaczono najmniejsza i największą różnicę $\mathrm{w}$ wartościach temperatury uzyskanych $\mathrm{z}$ pomiaru termowizyjnego oraz stykowego. Następnie zgodnie z zależnością (1) wyznaczono błąd względny procentowy na podstawie [5] pomiaru termowizyjnego względem pomiaru z zastosowaniem termopary.

$$
\delta=\frac{\left|x-x_{z}\right|}{x} \cdot 100 \%
$$

gdzie: $x$-pomiar przy użyciu termopary płaszczowej, $x_{z}$-pomiar uzyskany z kamery termowizyjnej.

W procesu konfiguracji kamery termowizyjnej oraz po zastosowaniu zależności (8) wyznaczono minimalny błąd kamery IR wynoszący 4\% oraz maksymalny $17 \%$ względem pomiaru kontaktowego.

Po wprowadzeniu wszystkich niezbędnych danych, kamere zamocowano w obudowie przymocowanej na podwoziu pojazdu do ramy wózka po przeciwnej stronie badanej tarczy, co przedstawia rysunek 7 . Kamera odsunięta była od badanego obiektu o około $1 \mathrm{~m}$.

Obserwację w czasie rzeczywistym rozkładu termowizyjnego jak i akwizycję obrazów realizowano za pomocą konwertera Video Grabber oraz dodatkowego oprogramowania Visual Studio 10. Konwerter umożliwiał zgrywanie analogowych sygnałów z karty termowizyjnej do postaci cyfrowej na dysku twardym komputera znajdującego się w badanym pojeździe przez port USB.

\subsection{Przebieg oraz wyniki badań termowizyjnych}

Pojazd z zainstalowaną na podwoziu kamerą termowizyjną wykonał jedno hamowanie $\mathrm{z}$ prędkości 100 $\mathrm{km} / \mathrm{h}$ oraz trzy hamowania z prędkości $140 \mathrm{~km} / \mathrm{h}$. Wszystkie hamowania wykonane były jako nagłe $\mathrm{z}$ użyciem hamulca pneumatycznego PN. Do prób wybrano odcinek prosty toru bez pochylenia. W czasie badań, rozkład temperatury tarczy rejestrowano w sposób ciagły nagrywając filmy z przebiegu procesu hamowania. Wybrane obrazy z nagrywania rozkładu temperatury tarczy $\mathrm{w}$ czasie hamowania przedstawia rysunek 8 .

Przykładowy wykres zamiany temperatury tarczy w czasie nagłego hamowania z prędkości $140 \mathrm{~km} / \mathrm{h}$ na trzech promieniach tarczy przedstawia rysunek 9 . 
Real-time observation of the thermal distribution and image acquisition were carried out using the Video Grabber converter and additional Visual Studio 10 software. The converter made it possible to download analog signals from the thermal imaging camera to digital form on the hard drive of the computer in the tested vehicle via a USB port.

\subsection{The process and results of thermal imaging tests}

The vehicle with the thermal imaging camera installed on the chassis performed one braking action decelerating from a speed of $100 \mathrm{~km} / \mathrm{h}$ and three braking actions decelerating from a speed of $140 \mathrm{~km} / \mathrm{h}$. All braking was performed suddenly using the PN air brake. A straight section of the track without incline was selected for the tests. During the tests, the temperature distribution in the brake disc was recorded continuously as a video capture by the camera from the entire braking process. Selected images from the recordings of the brake disc temperature distribution during braking were provided in Figure 8.

An example of the disc temperature change during sudden braking from a speed of $140 \mathrm{~km} / \mathrm{h}$ on three disc radii was shown in Figure 9.

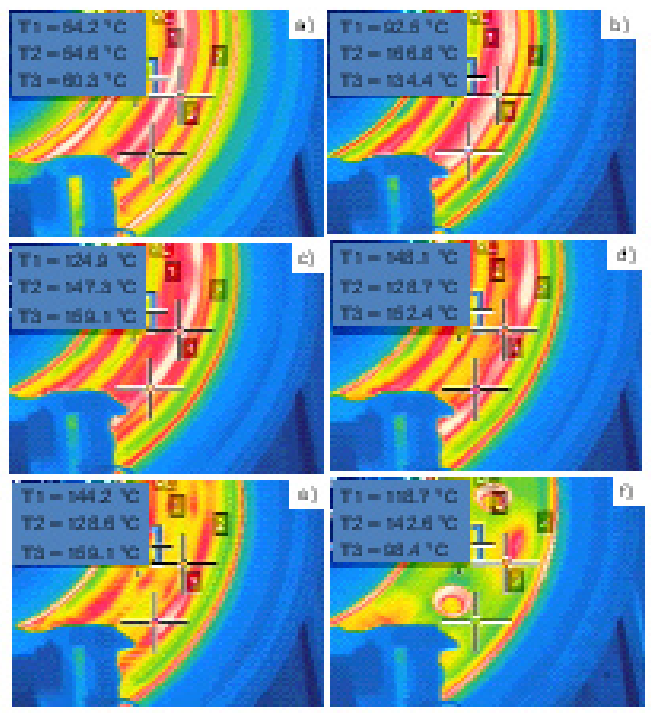

Fig. 8 Selected thermal images of the brake disc temperature distribution during emergency braking from a speed of $140 \mathrm{~km} / \mathrm{h}$; a) 2 seconds of braking, b) 10 s of braking, c) $14 \mathrm{~s}$ of braking, d) $20 \mathrm{~s}$ of braking, e) 30s of braking, f) after vehicle stop

Rys. 8 Wybrane obrazy termowizyjne rozkładu temperatury tarczy hamulcowej w czasie hamowania nagłego z prędkości $140 \mathrm{~km} / \mathrm{h}$; a) 2 sekunda hamowania, b) $10 \mathrm{~s}$ hamowania, c) $14 \mathrm{~s}$ hamowania, d) 20s hamowania, e) 30s hamowania, f) zatrzymanie pojazdu

Figures 10 and 11 show the values of the average brake disc temperature before braking, the highest temperature in the entire braking process and the value at the moment of vehicle coming to a stop. Additionally, the relative percentage error, minimum and maximum, of the thermal imaging measurement resulting from the estimated emissivity using the calorimetric method was taken into account and shown as error bars.

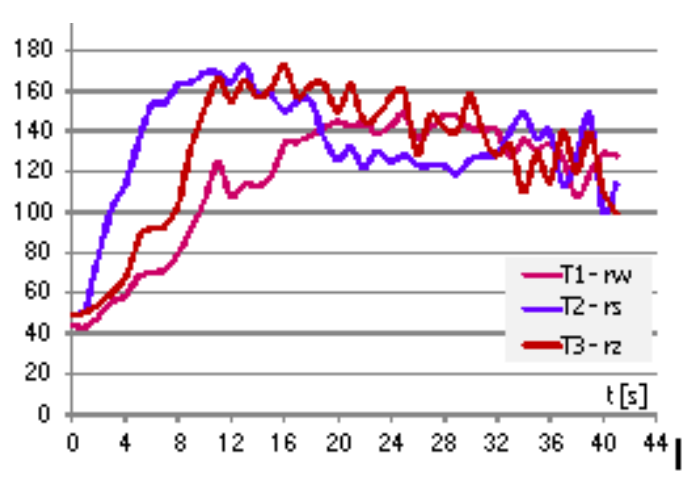

Fig. 9 Brake disc temperature distribution $(\mathrm{Tt})$ as a function of braking time $(\mathrm{t}$ ) from the speed $\mathrm{v}=140 \mathrm{~km} / \mathrm{h}$ (measurement on three radii of the brake disc, rw - inner radius, rs - secondary inner radius, $\mathrm{rZ}$ - outer radius, $\mathrm{T} 1, \mathrm{~T} 2$ and $\mathrm{T} 3$ - temperature measurement points at individual wheel radii points)

Rys. 9 Rozkład temperatury tarczy hamulcowej (Tt) w czasie hamowania (t) $P N$ z prędkości v=140km/h (pomiar na trzech promieniach tarczy hamulcowej, rw - promień wewnętrzny, rs promień wewnętrzny, rz - promień zewnętrzny, T1, T2 i T3 punkty pomiaru temperatury na poszczególnych promieniach )

Na rysunkach 10 i 11 przedstawiono wartości średniej temperatury tarczy przed hamowaniem, najwyższej $\mathrm{z}$ całego procesu hamowania oraz $\mathrm{w}$ chwili zatrzymania. Dodatkowo uwzględniono błąd względny procentowy minimalny oraz maksymalny pomiaru termowizyjnego wynikającego $\mathrm{z}$ oszacowanego współczynnika emisyjności metodą kalorymetryczną.

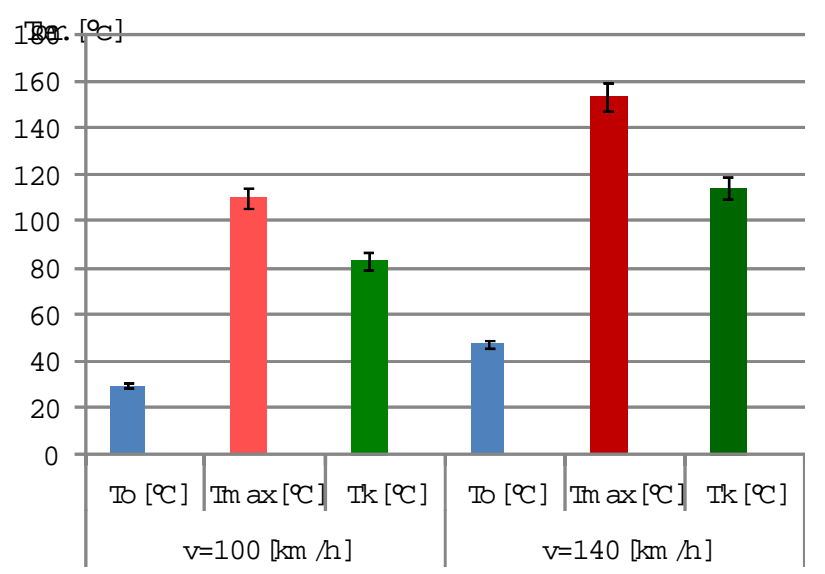

Fig. 10 Summary of average values (Tśr.) Of the brake disc temperature before braking (To), the highest temperature during braking (Tmax) and at the moment of stopping (Tk) with $4 \%$ relative percentage error

Rys. 10 Zestawienie wartości średnich (Tśr.) temperatury tarczy hamulcowej przed hamowaniem (To), najwyższej w czasie hamowania (Tmax) oraz w chwili zatrzymania (Tk) z uwzględnieniem $4 \%$ błędu względnego procentowego

Zestawienie końcowe maksymalnych wartości temperatur tarczy hamulcowej z uwzględnieniem błędu pomiarowego dla dwóch prędkości hamowania w czasie hamowań nagłych z zastosowaniem hamulca pneumatycznego PN przedstawia tablica 1. 


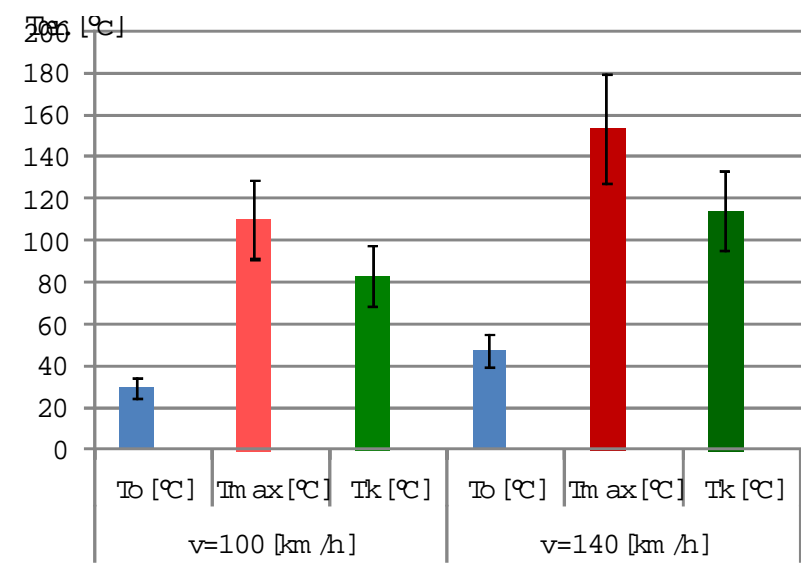

Fig. 11 Summary of average values (Tśr.) Of the brake disc temperature before braking (To), the highest temperature during braking (Tmax) and at the moment of stopping (Tk) with $17 \%$ relative percentage error

Rys. 11 Zestawienie wartości średnich (Tśr.) temperatury tarczy hamulcowej przed hamowaniem (To), najwyższej w czasie hamowania (Tmax) oraz w chwili zatrzymania (Tk) z uwzględnieniem $17 \%$ błędu względnego procentowego

The final list of maximum values of brake disc temperatures, taking into account the measurement error for two braking speeds during emergency braking with the use of the PN air brake, was presented in Table 1.

When analyzing the obtained values of the maximum temperature of the brake disc, while taking into account the maximum measurement error for the thermal imaging method, no values were found to exceed 180 ? C. During the tests of the DB Link III vehicle, the braking was performed on an empty vehicle, where the service weight was $82 \mathrm{t}$. The vehicle in the three-unit version is based on 4 bogies, hence the braking mass per one brake disc was about 5 tons.

\section{Bibliography / Bibliografia}

[1] Hotyst R, Poniewierski A, Ciach A.: Termodynamika dla chemików, fizyków i inżynierów. Instytut Chemii Fizycznej PAN i Szkoła Nauk Ścistych, Warszawa 2003.

[2] https://www.rynek-kolejowy.pl/mobile/w-pesie-jest-corazwiecej-linkow-dla-db-kiedy-dostawa--84183.html

[3] https://www.fachowyinstalator.pl/kamery-termowizyjne-

[4] zasada-dzialanial

http://www.northerntool.com/shop/tools/product 2004722 24_200472224

[5] Krysicki W, Włodarski L.: Analiza matematyczna $w$ zadaniach, Wydawnictwo PWN, Warszawa 2007.

[6] Oliferuk W.: Termografia podczerwieni $w$ nieniszczqcych badaniach materiatów $i$ urzqdzeń, Biuro Gamma, Warszawa 2008.

[7] Pudlik W.: Termodynamika. Wydawnictwo Biblioteka Gtówna Politechniki Gdańskiej, Gdańsk 2011.

[8] Rudowski G.: Termowizja i jej zastosowanie, Wydawnictwa Komunikacji i Łaczności, Warszawa 1978.

[9] Sawczuk W.: Zjawiska nieliniowe w strefie kontaktu oktadziny ciernej z tarcza hamulcowa pojazdu szynowego. Wydawnictwo Politechniki Poznańskiej, Poznań 2019.

[10] Sobieski W.: Termodynamika w eksperymentach, skrypt dla studentów, Olsztyn 2015.

[11] Więcek B., De Mey G.: Termowizja w podczerwieni podstawy $i$ zastosowania. Wydawnictwo PAK, Warszawa 2011. 34-43.
Table 1. List of maximum brake disc temperatures of the DB Link III 633 series vehicle including the measurement error for the thermal imaging method

Tablica 1. Zestawienie wartości maksymalnych temperatur tarczy hamulcowej pojazdu DB Link III serii 633 z uwzględnieniem błędu pomiarowego dla metody termowizyjnej

\begin{tabular}{|c|c|c|}
\hline $\begin{array}{c}\text { Thermal imaging } \\
\text { error [\%] }\end{array}$ & $\begin{array}{c}\text { Braking from a } \\
\text { speed of } \mathrm{v}=100 \\
{[\mathrm{~km} / \mathrm{h}]}\end{array}$ & $\begin{array}{c}\text { Braking from a } \\
\text { speed of } \mathrm{v}=140 \\
{[\mathrm{~km} / \mathrm{h}]}\end{array}$ \\
\hline $\begin{array}{c}\text { Błąd pomiaru } \\
\text { termowizyjnego } \\
{[\%]}\end{array}$ & $\begin{array}{c}\text { Hamowanie } \mathrm{z} \\
\text { prędkości } \mathrm{v}=100 \\
{[\mathrm{~km} / \mathrm{h}]}\end{array}$ & $\begin{array}{c}\text { Hamowanie } \mathrm{z} \\
\text { prędkości } \mathrm{v}=140 \\
{[\mathrm{~km} / \mathrm{h}]}\end{array}$ \\
\hline Min. 4 & $114,1\left[{ }^{\circ} \mathrm{C}\right]$ & $159,5\left[{ }^{\circ} \mathrm{C}\right]$ \\
\hline Max. 17 & $128,3\left[{ }^{\circ} \mathrm{C}\right]$ & $179,5\left[{ }^{\circ} \mathrm{C}\right]$ \\
\hline
\end{tabular}

Analizując uzyskane wartości maksymalnej temperatury tarczy hamulcowej z uwzględnieniem maksymalnego błędu pomiaru dla metody termowizyjnego, nie stwierdzono wartości przekraczających 180 ? C. Podczas badań pojazdu DB Link III, hamowania wykonane były dla pojazdu nieobciążonego, masa służbowa wynosiła 82 t. Pojazd w wersji trzyczłonowej oparty jest na 4 wózkach, wówczas masa do wyhamowania przypadająca na jedną tarczę wyniosła około 5 t.

\section{Podsumowanie}

W artykule przedstawiono metodykę badań termowizyjnych hamulca tarczowego w warunkach rzeczywistych na pojeździe DB link III. Zwrócono szczególną uwagę na konfigurację kamery IR w zakresie wyznaczenia współczynnika emisyjności, mającego największy wpływ na dokładność pomiaru termowizyjnego. Przedstawiono trzy metody wyznaczenia współczynnika $\varepsilon$, natomiast dla metody kalorymetrycznej zaprezentowano sposób wyznaczenia współczynnika emisyjności dla badań rozkładu temperatury tarczy hamulcowej pojazdu DB link III. Przy zastosowaniu termometru z sondą dotykową dla kilku obszarów tarczy hamulcowej dokonano wyznaczenia współczynnika $\varepsilon$ w celu uzyskania zbliżonych wartości temperatury dla obu przyrządów pomiarowych. Na tej podstawie określono minimalny i maksymalny błąd pomiaru. Podczas badań pojazdu $\mathrm{w}$ czasie hamowania $\mathrm{z}$ prędkości maksymalnej wynoszącej $140 \mathrm{~km} / \mathrm{h}$ w stanie próżnym nie stwierdzono przekroczenia temperatury 180 ? C na tarczy hamulcowej. 